\title{
Influence of Teaching Style on Pupils Engagement in Physical and Sport Education in Grammar School of Brazzaville
}

\author{
Mabassa David Sylvain ${ }^{1}$, Itoua Okemba Jean ${ }^{1,2}$, Fernandes Balou Gabin ${ }^{1,2}$, \\ Mabialas Josiane Marinick Suzie3 ${ }^{3}$ Mouanda Lumiere De-Consentie ${ }^{1}$
}

${ }^{1}$ Laboratoire de Didactique des Activités Physiques et Sportives, Institut Supérieur de l'Education Physique et Sportive (ISEPS), Université Marien Ngouabi, Brazzaville, Congo

${ }^{2}$ Laboratoire d'Etudes et de Recherches en Activités Physiques Adaptées, Institut Supérieur de l'Education Physique et Sportive (ISEPS), Université Marien Ngouabi, Brazzaville, Congo

${ }^{3}$ Laboratoire des Sciences Humaines et Sociales, des Activités Physiques et Sportives, Institut Supérieur de l'Education Physique et Sportive (ISEPS), Université Marien Ngouabi, Brazzaville, Congo

Email: *dmabassa@googlemail.com

How to cite this paper: Sylvain, M. D., Jean, I. O., Gabin, F. B., Suzie, M. J. M., \& De-Consentie, M. L. (2019). Influence of Teaching Style on Pupils Engagement in Physical and Sport Education in Grammar School of Brazzaville. Advances in Physical Education, 9, 303-313.

https://doi.org/10.4236/ape.2019.94021

Received: August 6, 2019

Accepted: November 12, 2019

Published: November 15, 2019

Copyright $\odot 2019$ by author(s) and Scientific Research Publishing Inc. This work is licensed under the Creative Commons Attribution International License (CC BY 4.0).

http://creativecommons.org/licenses/by/4.0/

(c) (i) Open Access

\begin{abstract}
The aim of the study is to analyze whether the teaching style in Physical and Sport Education (PSE) influences the involvement of students in learning. The theory that non-interference, democratic and authoritarian styles of teaching at different times in the same physical and sport education lessons promotes student engagement in the building of motor skills. Our study took place in Brazzaville in public grammar school. A sample of 20 Physical and sport education teachers and 321 grade 4 and 3 students took part in the experiment. A questionnaire was distributed to students to determine the causes of their commitment to the teacher's perception of the personality, the representations of the physical and sport education discipline and the teaching styles used by the teacher similarly, another questionnaire prepared was intended for teachers to analyze learning situations and to interpret teachers' behaviours. The results show that $52 \%$ of pupils are involved in "learning and progress" learning with the authoritarian style, $58 \%$ of pupils are involved in learning "maintain order in physical and sport education" with the authoritarian style, against $40 \%$ of students are involved in learning to "get involved" with the non-interference style and $53 \%$ of students are involved in learning to "have fun" with the democratic style. In conclusion, the physical and sport education teachers favor much more the authoritarian style during the lessons of physical and sport education, in the Grammar schools of Brazzaville.
\end{abstract}




\section{Keywords}

Teachers, Physical and Sport Education, Teaching Style, Students'

Engagement

\section{Introduction}

Physical and Sport Education (PSE) is a teaching discipline. It generates a set of knowledge constituted in a transmissible form for schooling, in the same way as the other so-called seated disciplines. For Durand (1996), the PSE is a particular discipline that "puts the clean body into play". In other words, his teaching requires a commitment of students in the construction of learning, a representation of the discipline and a style of teaching. Teaching style is one way for teachers to set skills and conduct the physical and sport education lesson. That is to say to organize the workshops, the management of the physical and social life, the maintenance of the motor performance. For students, each discipline would correspond to a dominant teaching style; this style would be authoritative in mathematics, French or geography-history, and more relaxed in music education and physical and sport education. So each discipline is correlated to a particular teaching style. There is a mismatch between the representations of today's students and the teaching styles of "yesterday".

This refers to the models that the physical and sport education teacher has experienced and which have proven effective. The school model is based on teaching practices, which is characterized by a twisting of the "master" mode for the transmission of knowledge, psychic dimensions, and group dimensions in learning situations (Mendel, 2002).

Indeed, teaching styles must adapt to the Sustainable development Objectives (SDO): take into account the physical needs of students. It is obvious that didactic innovation has a positive influence on the meaning of learning and student motivation. This innovation must not make the shadows existing pedagogical processes. Our study conducted in the Grammar school of Brazzaville helps us to understand the didactic relationship existing between the style of teaching and the motor engagement of the students. The study makes an original contribution to the extent that the Congolese researches encountered in this field are insufficient.

However, the fundamental problem raised in this study is to believe, whether it is the teaching style that constitutes the didactic obstacle to the students or if it is the way to use it continually to teach which disturbs them. In this regard, the formative evaluations highlight the lack of "dramatization" in the teaching of physical and sport education and this manifests itself in a rather distant relationship marking the authoritarian behaviour of the teacher towards the pupils, for the purpose of not losing control of the class.

However, students are more involved when we are less authoritarian and 
create less disorder. Given this observation, we will analyze the teaching styles available to the teacher of physical and sport education to involve more students in their learning.

Thus, our study answers two questions:

- How would teach styles involve students in physical and sport education learning?

- At what point in the physical and sport education lesson, would the authoritarian teaching style promote student engagement in the construction of learning?

In an attempt to answer these questions, we have formulated the following hypothesis:

"The authoritarian teaching style at different times in the same physical and sport education lesson promotes student involvement in learning".

In carrying out this study, we set ourselves the following objectives:

- Improve the different teaching styles to involve students in learning in physical and sport education.

- To know at what period of the lesson of physical and sport education, the teacher uses non-interference, democratic, authoritarian teaching styles. The interest of this study is to bring the authorities of the education system to take a text which regulates the style of teaching in physical and sport education in Congolese schools.

\section{Materiel and Methods}

Our study took place in general education colleges, in the urban community of Brazzaville. The trial period was between November 20, 2017 and April 30, 2018.

The colleges surveyed had complete cycles from grades 6 to 3 . They had 2,300 students, 142 administrative staff and 96 teachers. The target population concerned by the experimentation was composed of 35 PSE teachers and 754 pupils at the 4th and 3rd grade level.

From this population, a sample of 20 PSE teachers ( 12 males and 8 females) and 321 students (141 females and 180 males) meeting the selection criteria below was selected after the $1 / 10$ draw.

For teachers:

- Be a state agent, a public servant;

- Have a schedule;

- To enjoy good moral and physical health.

For the students:

- Be regular in physical and sport education class;

- Be registered officially;

- To be in a good health.

\subsection{Application Classes' Infatuation}

During the course of the physical and sport education cycles, the classes were 
observed in speed and gymnastics in the 1st cycle, then in volleyball and handball 2nd cycle. These classes were heterogeneous in terms of skills, investment and student motivation. However, girl students were passive, very rarely volunteering in the practice of Physical, Sport Activity and Artistic (PSAA) because they exhibited incorrect behaviors. The students also have varied representations of the physical and sport education discipline and some PSAA that they sometimes consider to be restrictive and/or unnecessary. The pedagogical classes thus presented strong characteristics which we took into account during the experimentation.

\subsection{Experimental Protocol}

Experiments concerned both the teacher and the students. In fact, it was a matter of retrieving information from the teacher and the students, then confronting these two points of view. The goal was to change the behavior of the teacher by making him aware of the different teaching styles possible and a time to change. The intervention was better adapted to the different learning situations, and the effectiveness of its relationship with the students of 4 th and 3rd was better.

\subsection{Conduct of the Experiment}

Firstly, a questionnaire was distributed to students, to determine their representations of the physical and sport education discipline, the causes of their involvement in it, the most effective teaching style according to them, and their perception of the personality of the student teacher.

Secondly, a handball lesson was constructed and filmed, so that three different teaching styles would appear distinctly during the course of the same physical and sport education lesson.

Thus, warm-up was conducted according to a non-interference style:

- The students had no special instructions except that they had an undefined time to warm up autonomously. The teacher did not intervene at any time during the PS lesson.

The learning situation was done with a democratic style:

- From a situation in which a student had to score a goal while being pursued by a defender. The starting point of the defender was removed from the attacker's from the start, which made his intervention difficult. The students then proposed to bring the starting point of the defender closer to facilitate his return on the attacker.

Finally, the theme games at the end of the lesson were based on an authoritarian style:

- An exempt student was instructed to referee the match and to sanction all the mistakes made during the game, without taking into account the remarks of the pupils.

At the end of this lesson, the students answered a questionnaire about the different teaching styles used by the teacher. This so, that they determine the style 
that suits them best to work. Thirdly, then, in order to better interpret and analyze the situations that had just been presented, the teacher responded to the following lesson, to a questionnaire prepared by Treutlin (1995) about teacher behavior. After a few days of taking a step back, the teacher answered the questionnaire again to note whether the importance given to certain events was stable.

\subsection{Statistical Analysis}

In order to have a readability of our results and to make a good use of them, the calculation of percentage was retained, question of counting the relative frequency accumulated by the pupils in the implication of the learning situations proposed by the physical and sport education teacher.

\section{Results}

\subsection{Involvement of Students in the Construction of Motor Learning}

The analysis of the results of the questionnaire for students on their implications for PSE learning is presented in Table 1.

La lecture faite des résultats du Table 1 révèle que les élèves s'impliquent à $52 \%$ dans les apprentissages "apprendre le dribble et progresser avec la balle" grâce au style autoritaire de l'enseignement.

Les résultats du Table 2 indiquent que le style laisser-faire utilisé $40 \%$ par l'enseignant intègre l'implication des élèves dans les apprentissages "s'investir dans le match".

L'enregistrement des résultats obtenu du Table 3 montre que une détermination nette de $53 \%$ des élèves à dans le style démocratique, comparativement aux styles autoritaire et laisser-faire.

L'interprétation des résultats du Table 4, nous fait remarquer que $58 \%$ du style autoritaire est apprécié par les élèves dans l'apprentissage "maintenir l'ordre dans le règlement".

Table 1. Students' involvement in learning "Learning to dribble and to progress with the ball”.

\begin{tabular}{ccc}
\hline & Effective $(\mathrm{N}=321)$ & Frequency (\%) \\
\hline Leave to do & 61 & 19 \\
Democratic & 93 & 29 \\
Authoritarian & 167 & 52
\end{tabular}

Table 2. Involvement of students in learning "Investing in the match".

\begin{tabular}{ccc}
\hline & Effective $(\mathrm{N}=321)$ & Frequency $(\%)$ \\
\hline Leave to do & 129 & 40 \\
Democratic & 96 & 30 \\
Authoritarian & 96 & 30
\end{tabular}


Table 3. Involving students in learning "Enjoying the game organization".

\begin{tabular}{ccc}
\hline & Effective $(\mathrm{N}=321)$ & Frequency (\%) \\
\hline Leave to do & 151 & 47 \\
Democratic & 170 & 53 \\
Authoritarian & 0 & 0 \\
\hline
\end{tabular}

Table 4. Student involvement in learning "Keeping order in regulation".

\begin{tabular}{ccc}
\hline & Effective $(\mathrm{N}=321)$ & Frequency (\%) \\
\hline Leave to do & 35 & 11 \\
Democratic & 99 & 31 \\
Authoritarian & 187 & 58 \\
\hline
\end{tabular}

\subsection{Student Engagement by Teaching Style during Physical and Sport Education Course}

The physical and sport education lesson, which resulted in 3 different teaching styles, was followed by a student quiz, which shows the following results:

The analysis of the results in Table 5 shows that student investment is very important (39\%), compared to pleasure, disorder in physical and sport education and motor learning.

Reading Table 6 reveals that the pleasure experienced by students is higher (32\%), the disorder in Physical and sport education is under control (5\%), while the investment falls (11\%). The intervention of the PSE teacher does not seem to apply to all students.

The recording of the results obtained in Table 7 shows that with authoritarian style, investment (50\%), learning (45\%), pleasure (45) and disorder in EPS (15\%), obtain significant performance.

\subsection{Answers of the Teacher to the Questionnaire of Treutlin} (1995)

L'analyse des réponses issue du questionnaire destiné aux enseignants sur la manière de conduire la leçon d'EPS est présentée dans le Table 8.

\section{Discussion}

The analysis of the results obtained in Tables 1-4, relating to the questionnaire intended for the pupils on their commitments in the apprenticeships in PSE, shows that the expectations of the pupils are heterogeneous, we can say without risk to be mistaken that the style of instruction desired by the students differs according to the reason for their participation in the PSE course. Thus, to "learn to dribble and progress with the ball", the style "authoritarian" is the most sought $(52 \%)$, to invest in the game, the "non interference" style dominates $(40 \%)$, take pleasure in the organization of the game, the "democratic" style prevails (53\%), finally for a certain order is maintained in physical and sport education the "authoritarian" style comes first (58\%). 
Table 5. Presentation of the "non-interference" teaching style during warm-up.

\begin{tabular}{cccc}
\hline & Not at all (\%) & A little (\%) & A Lot (\%) \\
\hline Investment & 11 & 50 & 39 \\
Engine learning & 22 & 66 & 10 \\
Fun in PSE & 10 & 65 & 21 \\
Disorder in PSE & 10 & 65 & 21 \\
\hline
\end{tabular}

Table 6. Presentation of the "democratic" teaching style during the exchange situation.

\begin{tabular}{cccc}
\hline & Nothing (\%) & A few (\%) & A lot (\%) \\
\hline Investment & 21 & 50 & 28 \\
Engine learning & 28 & 60 & 32 \\
Fun in P. Sport Education & 10 & 55 & 14 \\
Intervention of the teacher & 30 & 55 & 05 \\
Disorder in P.S.E & 32 & 61 & \\
\hline
\end{tabular}

Table 7. Presentation of "authoritarian" teaching style during games.

\begin{tabular}{cccc}
\hline & Nothing (\%) & A little (\%) & A lot (\%) \\
\hline Investment & 18 & 32 & 50 \\
Engine learning & 22 & 33 & 45 \\
Fun in P. Sports Education & 11 & 44 & 45 \\
Disorder en PSE & 33 & 50 & 15 \\
\hline
\end{tabular}

Table 8. Présentation des réponses données par les enseignants d’EPS.

\begin{tabular}{|c|c|c|}
\hline $\mathrm{N}^{\circ}$ & Questions & Replies \\
\hline 1 & $\begin{array}{l}\text { - What is the situation chosen and how } \\
\text { do you describe it? }\end{array}$ & $\begin{array}{l}\text { - The setting is the chosen situation. It was done } \\
\text { according to the teaching style } \\
\text { "non-interference". We call it "Inactivity". }\end{array}$ \\
\hline & $\begin{array}{l}\text { - Have you thought about the importance } \\
\text { of the situation? }\end{array}$ & - Yes \\
\hline 2 & - Is the situation important to you? & - Very important \\
\hline & - Why does the situation matter? & $\begin{array}{l}\text { - It allows students to be in physical condition, } \\
\text { to avoid muscle, ligament and joint accidents }\end{array}$ \\
\hline 3 & $\begin{array}{l}\text { - Have you thought about the causes of } \\
\text { the evolution of this situation? }\end{array}$ & - Yes \\
\hline 4 & $\begin{array}{l}\text { - Have you thought about the critical } \\
\text { incident of the Physical Education and } \\
\text { Sports lesson? }\end{array}$ & - Yes \\
\hline \multirow{3}{*}{5} & $\begin{array}{l}\text { - What types of emotions did you notice } \\
\text { during the course of the situation? }\end{array}$ & Courage, fear, stress, composure, fair play \\
\hline & $\begin{array}{l}\text { - Has your emotional situation been } \\
\text { dominated by the student's behaviour? }\end{array}$ & $\begin{array}{l}\text { Yes, by the way of performing the proposed } \\
\text { motor tasks }\end{array}$ \\
\hline & $\begin{array}{l}\text { - If so, how did you feel during the } \\
\text { critical incident (adjective/term)? }\end{array}$ & $\begin{array}{l}\text { - Curious, enthusiastic with the desire to } \\
\text { realize, to demonstrate a motor image }\end{array}$ \\
\hline
\end{tabular}




\section{Continued}

\begin{tabular}{|c|c|c|}
\hline \multirow{2}{*}{6} & $\begin{array}{l}\text { - Have you thought about the physical } \\
\text { needs of students? }\end{array}$ & Yes, run, jump, play, ... \\
\hline & - If yes, in what context/when? & $\begin{array}{l}\text { During the warm-up, in a physiological } \\
\text { context }\end{array}$ \\
\hline 7 & $\begin{array}{l}\text { - Did you give other instructions before } \\
\text { acting? }\end{array}$ & $\begin{array}{l}\text { - Yes, relaxation instructions, recovery after } \\
\text { exercise }\end{array}$ \\
\hline \multirow{2}{*}{8} & $\begin{array}{l}\text { - What was the purpose of your } \\
\text { warm-up? }\end{array}$ & - Stretch, soften and strengthen muscle groups \\
\hline & - If yes, which ones? & $\begin{array}{l}\text { The deltoid, rhomboid, Deltoid, rhomboid, } \\
\text { quadriceps }\end{array}$ \\
\hline \multirow[t]{2}{*}{9} & $\begin{array}{l}\text { - Have you thought of other goals before } \\
\text { making your choice of action? }\end{array}$ & - No \\
\hline & $\begin{array}{l}\text { - Do you have expectations about the } \\
\text { consequences of your action? }\end{array}$ & - Yes \\
\hline 10 & If yes, which ones? & $\begin{array}{l}\text { To make them understand that I was not } \\
\text { satisfied with their answers, but also that the } \\
\text { work in autonomy, without my intervention, } \\
\text { does not exempt from work. Also, know that } \\
\text { they are not doing the required task seriously, } \\
\text { they are doing it again. }\end{array}$ \\
\hline 11 & $\begin{array}{l}\text { Describe in a few words the chosen } \\
\text { action: How did you act? }\end{array}$ & $\begin{array}{l}\text { We introduced ourselves to the students } \\
\text { serene and strong to tell them that they were } \\
\text { going to warm up again because they had not } \\
\text { done it properly. }\end{array}$ \\
\hline
\end{tabular}

The personal commitment of the student in the physical and sport education course corresponds to a particular style of teaching more favourable to the realization of it. It seems interesting to note that students feel that with an authoritarian style of teaching pleasure is not possible. Continuously teaching in one "authoritarian" mode of instruction, therefore, is a primary objective for students, focused on maintaining a certain level of PSE so that they can learn and progress in work. We can then believe that we put in the background their enjoyment, which is one of the causes of their investment, and therefore their learning (Epstein, 2001).

However, the teacher's behaviour establishes a certain distancing with the students, which can sometimes make him look like a "serious" teacher. Nevertheless, the students perceive the teacher as demanding but friendly. They are therefore able to understand that the teacher's attitude during physical and sport education is to seek above all an efficient and effective work. Moreover, it seems that for the students, the ideal teacher is not the one who masters a single teaching style perfectly, but rather the one who manages to alternate the three styles: personal style, relational style and didactic style (Altet, 1994, 1997). Also, students judge the teacher from different angles and not only under his repressive side. We think that in the eyes of the students, the teacher "humanizes" and becomes more affordable. It is, therefore, easier for students to communicate with 
the teacher about their learning difficulties, and thus to be more involved in overcoming them and proving them to the teacher.

The analysis of the results of the data highlights several important points:

First, it appears that each student has a personal representation of the physical and sport education discipline, which influences his participation in the PSE course, and more precisely the causes of this participation. (Learning, demonstration of the motor image, realization of gymnastic elements, acrobatic, aesthetic, pleasure, progress...). Each pupil, therefore, has a different motivation when he comes to PSE, and this is accentuated by the physical activity offered, rather than by the teacher concerned. For Blake \& Mouton (1987), these styles are determined from a two-dimensional model that combines two attitudes of the teacher: attitude towards the discipline and physical and sport education and attitude vis-à-vis students. Each of these attitudes is expressed in varying degrees, weak or strong, disinterest or interest. The combination of these two attitudes identifies four basic styles: the transmission style (entered on the discipline), the incentive style entered on both the discipline and the students), the associative style entered more about students), and the permissive style (very little entered on students or discipline).

However, in the light of Treutlin's (1995) questionnaire, it appears that the "non interference" style poses a case of consciousness, particularly in relation to the inactivity of some students, once in autonomy. It is difficult for the rigorous teacher to accept this situation in which students do all or nothing. At first, the warm-up situation notes the basis and takes rhythm of physical and sport education lesson. Then, we realize that once in autonomy, students engage little, despite the presence of the teacher in the field. Finally, it is considered that the work of the PSE teacher is primarily "to educate, educate and train" the students in order to develop a reflection that promotes their adaptation to the world of work in full change and physical life in general, and that will make them true "citizens" cultivated and lucid. This is why the teacher resumes the warm-up despite the pupils' protests, to make them understand that even if the teacher does not intervene, the pupils are not exempt from work. Students must feel dissatisfaction with their attitude.

In this regard, Banville \& Amade-Escot (2001) revealed that the quality of teaching is considered to be a determining factor in student learning. This influence of the teacher on learning was demonstrated by Mosston's "range of teaching styles" which gave researchers a frame of reference for systematic analysis of teaching and learning in the field of physical and sport education. For Mosston \& Ashworth (1990), education is "governed by a single process: decision-making".

Nevertheless, when we compare the results of the first questionnaire with those of the second one, we can note that in practice and contrary to what they say before, the pupils invest themselves more and take more pleasure in the organization of the game with the "authoritarian" style, while the order in the physical and sport education lesson seems to be obtained with the "democratic" style. 
The "non-interference" style meanwhile strongly favours investment, but seems unfavourable for motor learning. It is also with this style that the disorder in physical and sport education is the most obvious.

And with the "democratic" style, the disorder is less. Moreover, it is with this style that we note that the interventions, corrections, demonstrations of the physical and sport education teacher did not necessarily address all at the same time. This is because the teacher filmed the lesson, and as a result his availability was felt.

However, it is with the "authoritarian" style that the different items are the highest. Henceforth, the "authoritarian" style is less prominent in the lessons of physical and sport education. For Durand (1996), the teacher uses it when structuring the game teams, clubs, organizing workgroups by workshop, student mobility, respect for the rules of collective life the establishment and maintenance of a certain order, these to express important instructions, or for students to understand that the point is essential. When problem-solving situations are put in place, the "democratic" style is used to engage students and bring meaningful responses to their homes. As soon as the students are started in the learning tasks they are allowed to manage them, which allows us to intervene on a case by case basis to interest some students, to encourage others, to correct errors and to spread the contents of education. We are now trying to use several teaching styles, and to vary their frequency of appearance.

This change in the teacher's behavior means that there is more interaction with students, and their involvement is more important. In the same idea, but at the didactic level, the situations we propose seek to be simpler but also more playful. The teaching style may be used to create a learning-friendly PSE climate, but it seems that they need to be accompanied by more motivating situations for students. Here, it is important to point out that each teaching style has been tested in a distinct learning situation, which puts into perspective the results obtained in Tables 5-7.

Also, with the questionnaire, we realize that beyond the teaching style used by physical and sport education teacher, it seems that what promotes the pleasure of the organization of the game and the investment to learn this is the situation in which the pupil is placed.

In the light of the above, our experiment suggests some ways for the teacher of EPS to transform his behaviour and asks his students to become more involved in learning. However, we must relativize the results obtained to the extent that each style of teaching has not been tested in identical situations. The "authoritarian" style was performed in a very motivating match situation for the students, while the "non-interference" style took place during the warm-up. In addition, although the questionnaires were presented as study materials for another teacher, the fact remains that students may have biased their responses in order to "satisfy" the teacher.

Finally, the recording of the lesson by me decreased the presence among students, which may have played on the participation and seriousness of some. 
From a professional transformation perspective, the results obtained should be used by another beginning teacher of physical and sport education. The initial question that was asked was whether we could change the particular way we teach Physical and sport education, how to behave in order to better engage students in learning. But to be more meaningful, it would have been interesting to do the same PSE lesson three times, each time with a different teaching style.

\section{Conclusion}

Our study aimed to verify the influence of the teaching style in physical and sport education on student engagement in the construction of learning. The assumption that PSE teachers much more favor the authoritarian style in Brazzaville has been verified. Because, this style adapts better with the plethoric manpower, mobilizes the activity solicited in group, the craze and the mastery of the class, or the didactic content of the lesson of PSE. As proof, 52\% of students are involved in learning to learn and progress with the authoritarian style, 58\% of students are involved in learning to maintain order in PSE with the authoritarian style, against $40 \%$ of students are involved in learning to "get involved" with the laissez-faire style and $53 \%$ of students are involved in learning to "take pleasure" with the democratic style.

\section{Conflicts of Interest}

The authors declare no conflicts of interest regarding the publication of this paper.

\section{References}

Altet, M. (1994). The Professional Training of Teachers. Pedagogues and Pedagogy Collection (p. 264), PUF, Paris.

Altet, M. (1997). Pedagogies of Learning. Pedagogues and Pedagogy Collection, Paris: PUF.

Banville, D., \& Amade-Escot, C. (2001). In: L. S. Lino, R. T. Ornelas, F. C. D. Costa, \& M. Pieron, (Eds.), Proceedings of the AIESEP International Congress (p. 8). Funchal, Madeira, Portugal.

Blake, R., \& Mouton, J. (1987). The Two Dimensions of Management. Organization Editions (p. 222), Paris.

Durand, M. (1996). Education in Schools. PUF.

Epstein, J. (2001). School, Family, and Community Partnerships: Preparing Educators and Improving Schools. Boulder: West View Press.

Mendel, G. (2002). New Millennium, Libertarian Challenges. Authrity and Education Conference at the Institute Sociologie Psychanalyse (as an Extension of His Work "History of authority", in Albin Michel). Paris: Albin Michel.

Mosston, M., \& Ashworth, S. (1990). The Spectrum of Teaching Styles: From Command Discovery. New York: Longman.

Treutlin, G. (1995). Diagnosis and Changes in Teacher Behavior. EPS Review, 254. 